\title{
Sino-Japanese Agricultural Trade Friction Analysis and China's Countermeasures
}

\author{
Jie $\operatorname{Lin}^{1} \&$ Yunfeng $\mathrm{Wu}^{1}$ \\ ${ }^{1}$ School of Economics and Management, Changchun University of Science and Technology, Changchun 130022, \\ China \\ Correspondence: Jie Lin, School of Economics and Management, Changchun University of Science and Technology, \\ Changchun 130022, China. E-mail: mhymark@gmail.com
}

Received: October 4, 2013

Accepted: October 13, 2013

Online Published: November 4, 2013

doi:10.5430/bmr.v2n4p38

URL: http://dx.doi.org/10.5430/bmr.v2n4p38

\begin{abstract}
With the growing volume of Sino-Japanese agricultural trade, the agricultural trade friction between China and Japan has never stopped. In the good Sino-Japanese economic and trade development, the agricultural trade friction has always bothered the further improvement of Sino-Japanese economic and trade relationship. A great amount of Chinese agricultural products are exported to Japan, which benefits Japanese citizens to a great degree. However, due to the weak international competitive advantage of Japanese agriculture, Japan is bound to exaggerate the issue of agricultural protection. In this paper, authors give a brief review of the evolvement of Sino-Japanese agricultural trade friction, analyze the causes from three aspects, namely Japan, China, and international world, and finally put forward countermeasures for coping with Sino-Japanese agricultural trade friction respectively from three levels, namely the Government, agricultural association, and agricultural export enterprise.
\end{abstract}

Keywords: Japan, Agricultural product trade, Friction, Tactics

\section{The trade friction-related theories}

There are mainly two kinds of thoughts about the causes of trade friction. One is to analyze the causes of trade friction at the microeconomic level; the other is to analyze the causes of trade friction at the macroeconomic level. Microeconomic theory takes the perfect competition as a precondition. In a perfectively competitive market, there is no trade friction between countries; but if there is market failure, such as the international economic distortion between two countries, it will cause international trade friction. Use the macroeconomic balance equation, i.e. the relationship between external current balance of payment and domestic fiscal balance of payment, to explain the international trade friction, and conclude that it is the domestic factors that cause the trade friction, i.e. domestic private investment activities and Government fiscal revenue and payment activities. Therefore, we must focus on the domestic factors in order to ease the problem of international trade friction. For the essence of trade friction, one is because of the imbalanced economic development between countries, and the other is the competition for world market. Through the trade friction cases frequently happened between countries, we can know that the essence of trade friction is the fierce market competition between countries who try to enter the other's domestic market or occupy the third country's market.

\section{The review of Sino-Japanese agricultural trade friction history and the current status analysis}

For a long time, China has kept the trade black in the absolute quantity of Sino-Japanese agricultural trade. Japan is a typical country with demand for agricultural products. About one third of Chinese exported agricultural products enter Japan. In $21^{\text {st }}$ century, Sino-Japanese agricultural trade still maintains a good momentum of growth. In 2008, the import and export of agricultural products between China and Japan amounted to $\$ 9.886$ billion, increasing by $71.22 \%$, compared with the $\$ 5.774$ billion in 1997 . The annual growth rate reaches $5.01 \%$. Then, the global financial crisis broke out. In a complex trade environment with price volatility, economic recession, and food security crisis, China-to-Japan agricultural exports decreased to a negative growth in 2008 and 2009, which ended the continuous growing trend since the year 2003. In 2010, after the financial crisis, China-to-Japan agricultural exports resumed the positive growth and achieved a fast growth, being the highest for the past few years.

China has absolute agricultural competitiveness over Japan, which ensures China's advantages in trade. In Japan, most of agricultural products are less competitive. They import quite a lot agricultural products, but export few. They 
have always been in a disadvantage position that makes them adopt various measures to protect domestic producers. Once they adopt certain measure, it might trigger the trade friction. Especially for the labor-intensive agricultural products, China has the competitive advantage, and the export prices are generally lower than international market prices, which is more prone to cause agricultural trade friction between China and Japan. Some representative cases of Sino- Japanese agricultural trade friction include the 2001 Sino-Japanese onion event, the 2002 frozen spinach event, the 2003 "Hino Green" rush and rush products event, the 2004 Chinese bean vermicelli "benzoyl peroxide" event, etc.

Sino-Japanese agricultural trade friction covers an expanding area, with increasing influences. The trade friction has gradually developed from the one-product trade friction stage to the stage of entire-industry trade friction or even the structural trade friction. Trade friction might be caused by more diversified and hidden means. Reviewing the development process of Sino-Japanese agricultural trade friction, from the original tariff-caused trade friction to the anti-dumping and anti-subsidy-based trade friction, then to the technological barrier and safeguard-based trade friction, the forms are increasingly diversified and the means are more hidden and hard to be identified. Science \& technology has become the "killing approach" for Japan setting up trade barrier. Depending on the excellent research and development capabilities, Japan integrates science \& technology into the set-up of trade barriers. Japan often adopts new testing standards and releases new testing procedures, and conducts random checks on imported products occasionally. Once they find any kind of products exceeding the standards, they will limit the import of the batch of product or even the whole type of products by "one vote veto".

\section{The causes of Sino-Japanese agricultural trade friction}

The causes of Sino-Japanese agricultural trade friction could be divided into the international causes and the domestic causes. In the international aspect, today the world is in the trend of globalization. In the process of economic globalization and trade liberalization, the trade friction between countries would be inevitable, which is a fact and not easy to be avoided. The trade protectionism is rising in Japan. Because Japanese economy has been in a recession for a long period and demands are in a serious shortage, a group of trade protectionists comes into being in Japan. They attempt to build technological barriers for Chinese commodities and weaken the power of China's exports. In China's domestic aspect, if China's exports of agricultural products have quality problems, the unqualified agricultural products in market will harm the interests of consumers, thus damaging China's exports of agricultural products, and even causing the agricultural trade friction between the two countries. In China, agricultural products are low value-added, and do not develop certain special brands. Exports to Japan are mainly the labor-intensive products. Exporting a large number of low-tech, labor-intensive agricultural products often suffers restrictions of importing countries, causing trade friction.

\section{The countermeasures for China coping with Sino-Japanese agricultural trade friction}

With the continuous development of Sino-Japanese agricultural friction, the competition tends to be fiercer and Japan will control the imports more tightly, which might cause a new round of agricultural trade friction peak. In this case, China should not just take passive measures. What China should do is to actively improve the Sino-Japanese agricultural trade relationship and make sure that Sino-Japanese agricultural trade beat the damaging factors caused by the global economic crisis and achieve the stable and healthy development.

(1) The Government should develop the technological indicator system for agricultural production, strengthen the legislation, support the development of large agricultural enterprises, and build the friendly relationship with Japan. Make up the technological indicator system for the production of agricultural products and achieve the standardized production of agricultural products in China. Accelerate the Government legislation in fields of agricultural products' production, sales and quality, packaging, inspection and quarantine, so that the agricultural products' safety production and safety sales could be guaranteed by laws. Establish China's independent brands of agricultural products and improve the competitiveness of China's agricultural products. China should develop a more harmonious relationship with Japan and create a good circumstance for the bilateral trade to better promote the joint economic development in the two countries.

(2) Establish the agricultural association. When the agricultural trade friction happens, the agricultural association could represent the interests of its members to negotiate with importing enterprises. Japan implements the "Public-Private cooperation" system. Industrial associations, commercial associations, and other non-government institutions play important roles in the constitution of technological rules and standards. In the Sino-Japanese economic and trade exchanges, we should strengthen the communication and cooperation between private organizations of two countries, so that we can understand the relevant standards in the same trade in time, seize the new tendency of standards, and prepare ourselves properly for exporting to Japan. 
(3) Exporting enterprises should strengthen the understanding and application of WTO rules, improve the quality of agricultural products, adjust the export structure, and implement the market diversification strategy. The quality of agricultural products has always been a bottleneck of China's agricultural exports. Therefore, Chinese agricultural export enterprises should increase investments in science and technology, make effective technological innovations, and strive for improving the science \& technology elements of agricultural products. By this way, it might completely overcome the Sino- Japanese agricultural trade friction caused by the fact that exported agricultural products fail to meet the requirements of Japanese importing enterprises. Pursue for the achievement of whole-process quality and safety control from purchase to production and to transportation. In addition, strengthen the quality control on China's exports of agricultural products and attach importance to the international certification of agricultural products as well as in Japan on imports of agricultural products certification. Implement the market diversification strategy. China's agricultural products are mainly exported to Asia, especially Japan. The single market structure likely leads two consequences: one is the higher risk for China's agricultural export market; the other is that the single market structure might cause trade friction with the importing country. Therefore, we must implement the market diversification strategy and develop some developing markets with potentials, so that we can decentralize the exports of agricultural products and avoid the great market pressure caused by centralized exports on the importing country. In addition, China's exports of agricultural products should be diversified and differentiated in order to change the one-specie export structure.

\section{References}

Gao, Ruirong \& Cao, Bingru. (2011). Sino-Japanese agricultural trade and trade friction analysis. Jiangsu Commercial Forum, 12.

Li, Ju \& Wang, Houshuang. (2009). A study of Japan's experience in resolving the conflict of large countries' mutual reliance and trade clashes. Japan Studies, 3.

Shi, Qibao \& Cheng, Yongming. (2011). Japanese interest group influence mechanism in agricultural produce trade-friction between China and Japan. Japan Studies, 1.

Zhao, Xiaomeng. (2012). Sino-Japanese agricultural trade friction: present conditions, reasons, and countermeasure analysis. Modern Business Trade Industry, 4. 